\title{
Exploration of Spatial Design Issues at Backpacker Hostels in Budapest's Historic Center; Sebuah Review Terhadap Informality dan Adaptasi Desain di Kawasan Budapest, Hungaria
}

\author{
Ni Putu Suda Nurjani \\ ${ }^{1}$ Program Studi Teknik Industri, Fakultas Teknik, Universitas Mahendradatta \\ Jl. Ken Arok No.12, Peguyangan, Denpasar, Bali 80115 \\ Email: suda.nurjani@gmail.com
}

\begin{abstract}
Abstrak - Perubahan merupakan sebuah hal yang tidak bisa dihindarkan oleh setiap orang. Begitupun dengan perubahan sebuah kawasan sebagai sebuah fenomena yang tidak bisa dihindarkan oleh negara manapun yang ada di dunia. Banyak peneliti yang mencoba mengulas lebih jauh tentang fenomena perubahan sebagai sebuah bentuk adaptasi atau penyesuaian diri terhadap lingkungan yang baru. Namun, dalam mengembangkan sebuah kawasan banyak faktor yang harus dipertimbangkan. Ketika sebuah kawasan sebelumnya memiliki nilai sejarah yang cukup tinggi, perubahan menjadi sebuah hal teknis yang memerlukan kajian secara menyeluruh. Seperti penelitian yang dilakukan Gergely Horryn dkk (2017) ini. Dalam penelitian ini, Gergely Horryn dkk mencoba membuat sebuah alternative desain hostels untuk pengembangan kawasan Budapest, Hungaria. Mengingat tingginya nilai sejarah dari kota ini, maka penulis mempergunakan metoda komparasi literature dengan feedback desain dari hasil observasi lapangan. Rancangan perubahan dibuat berdasarkan pertimbangan nilai sejarah kota, interior ruangan, dan wujud bangunan yang akan ditampilkan. Dari beberapa fedbcak desain dibuat sebuah kesimpulan desain hostels cube yang kemudian diistilahkan dengan $\mathrm{Hc}$.
\end{abstract}

Kata kunci: Adaptasi, Hostels, Budapest

\begin{abstract}
Transformation is something that cannot be avoided by everyone. Like wise with the change of a region as a phenomenon that can not be avoided by any country in the world. Many researchers who try to review more about the phenomenon of change as a form of adaptation or adjustment to the new environment. However, in developing an area many factors must be considered. When a previous area has a high historical value, the change becomes a technical matter that requires a thorough study. Like this study by Gergely Horryn et al (2017). In this study, Gergely Horryn et al tried to make an alternative hostels design for the development of the Budapest, Hungary region. Given the high historical value of this city, the authors use the method of comparing literature with design feedback from field observations. The design changes were made based on consideration of the historical value of the city, the interior of the room, and the shape of the building to be displayed. From several fedbcak designs, a conclusion about the design of hostels cube are then termed Hc.
\end{abstract}

Keywords: Adaptation, Hostels, Budapest

\section{Pendahuluan}

Fenomena perubahan ruang spasial merupakan isu utama yang dihadapi oleh seluruh negara di dunia. Perkembangan jumlah populasi manusia di permukaan bumi, menuntut adanya adaptasi terhadap sebuah ruang spasial. Kata spasial berasal dari kata space dalam arsitektur secara sederhana diartikan sebagai ruang, namun pengertian space sendiri menurut para ahli memiliki pengertian yang berbeda-beda. Konsep ruang atau spasial mempunyai beberapa unsur, yaitu: jarak, lokasi, bentuk dan ukuran. Seperti posisi sebuah kursi dalam sebuah ruangan. Seberapa jauh jarak kursi itu dari 
dinding sebuah ruangan, di sudut manakah kursi itu diletakkan, bagaimana bentuk dasar kursi tersebut, serta seberapa tinggi ukuran kursi itu. Semua analisa terhadap posisi kursi dalam sebuah ruangan itu, dapat dikategorikan sebagai konsep spasial. Konsep ruang sangat berkaitan erat dengan waktu, karena pemanfaatan bumi dengan segala kekayaannya membutuhkan organisasi/pengaturan ruang dan waktu. Unsurunsur tersebut secara bersama-sama menyusun unit tata ruang yang disebut wilayah. Pengertian tata ruang dapat juga diklasifikasikan berdasarkan unit areal konkrit, fungsionalitas di antara fenomena, dan subyektifitas dalam penentuan kriteria (Budiharsono, 2001).

Mereview lebih jauh pada objek penelitian ini, dapat dilihat pembahasan sebuah kawasan pariwisata Budapest yang merupakan ibukota negara Hungaria, sekaligus merupakan kota terbesar di Hungaria. Budapest terletak di kedua tepi sungai Danube. Kota ini banyak memiliki bangunan bersejarah yang berasal dari tahun 1700-an sehingga mendapat pengakuan dari UNESCO sebagai situs warisan dunia pada tahun 1987 (https://id.wikipedia.org/wiki/Budapest). Dalam explorasi perubahan sebuah wilayah, ada beberapa variabel yang perlu diperhatikan diantaranya, faktor jenis bangunan, interior dan daerah dimana bangunan tersebut dibangun. Adapun issue yang diambil adalah budget akomodasi yang diperuntukkan khusus untuk kalangan backpacker, dengan penekanan penelitian yaitu informality. Salah satu faktor informality yang dimaksud disini adalah promosi dari mulut ke mulut, sehingga mengakibatkan akomodasi ini terkenal tanpa marketing yang legal. Variabel selanjutnya adalah kepadatan. Yang dimaksud kepadatan disini adalah bagaimana perkembangan pembangunan hostels di kawasan Budapest Hungaria dalam setahun terakhir, apakah lebih tinggi dari jumlah hostels yang ada di Prague atau Vienna, serta bagaimana cara bangunan-bangunan hostels ini bisa menyesuaikan diri. Satu sisi terdapat banyak permintaan hostels akibat tingginya tingkat kunjungan wisatawan, namun di sisi lain ada faktor kesejarahan dan budaya serta local wisdom yang harus tetap dipertahankan.

\section{Metode Penelitian}

Dalam meneliti tingkat adaptasi desain akomodasi wisata di kawasan Budapest, peneliti mempergunakan metoda RbD (Research by design). Penulis mendesign 6 (enam) backpacker hostel dalam periode tahun 2013-2015. Empat dari enam hostels tersebut sudah dioperasionalkan. Pengalaman penulis merupakan pengetahuan dasar dalam penelitian ini. Pengetahuan diperoleh melalui proses desain, praktek, dan pengamatan langsung di lapangan terhadap 6 (enam) Hostel yang khusus dibangun untuk wisatawan backpacker yang ada di Budapest dalam periode 2 (dua) tahun terakhir. Pengembangan design berdasarkan pengumpulan informasi backpacker lokal maupun internasional, konsultasi dengan manajer hostels, serta belajar dari former project. Bagian yang tidak terpisahkan dari penelitian ini adalah proses desain termasuk observasi terhadap existing hostels (dimana desain final dikembalikan lagi kepada pengguna untuk diuji kelayakannya, yang mana dianggap paling nyaman oleh pengguna), online review by guest, dan mengadakan feedback terhadap wisatawan maupun pihak manajemen hostels. Paper ini tidak hanya diperuntukkan untuk orang-orang yang ada dalam dunia desain, akan tetapi paper ini juga diperuntukkan kepada disiplin ilmu lain yang mendalami backpacker tourism. Desain adalah sebuah strategi riset yang merupakan implementasi dari hasil investigasi penulis terhadap fenomena backpacker hostels dan pengaruhnya terhadap urban structure dengan fokus pembahasan yaitu spatial isu. Hasil akhir dari penelitian ini menyatakan bahwa, terdapat 3 (tiga) faktor kunci urban dan arsitektur yang mempengaruhi karakteristik spesifik pembangunan hostels di kawasan Budapest yaitu, informality, density dan adaptability. Tiga faktor tersebut kemudian dikoneksikan dengan level, namely, kota, bangunan, interior serta furniture yang ada dalam hostels tersebut.

\section{Kajian Teori}

Permasalahan Backpacker Tourism hampir dihadapi oleh setiap negara yang ada di dunia, yang memiliki destinasi pariwisata. Isu backpacker menjadi penelitian yang sangat 
banyak dilakukan dewasa ini oleh peneliti dari berbagai disiplin ilmu. Dalam bidang pariwisata fenomena backpacker bisa dikaji berdasarkan karakteristik wisatawan, motivasi berkunjung, dan interaksi sosial (Murphy, 2001; Loker-Murphy and Pearce, 1995; Paris,2012). IImu manajemen sangat penting untuk menjaga keberlanjutan operasional backpacker (O'Regan, 2010). Selain itu banyak peneliti yang telah melakukan kajian tentang upaya peningkatan service dan operasional hostel (Borovskaya dan Dedova, 2014; Oliveira-Brochado dan Gamiero, 2013; Musa dan Thirumoorthi, 2011). Paris (2012) juga membahas tentang spasial issue dengan fokus penelitian yaitu faktor fisik dengan virtual space. Penelitian Timothy dan Teye's yang berjudul 'Tourism and The Lodging Sector' mendedikasikan sebuah bab yang khusus membahas tentang hostels yang mana mereka memperkenalkan pengguna yang ditulis berdasarkan nilai kesejarahannya (human behavior dan historical design).

Ruangan-ruangan yang ada di dalam hostels tersebut dibagi menjadi tiga fungsi yaitu ruang publik, ruang service dan privat area. Ruang publik termasuk receptionist, community space, dapur dan dinning area. Tujuan dari pembagian tiga zone ini adalah untuk membentuk hubungan spasial antar wisatawan. The informal, word-of mouth to mouth flow of information among guests is an essential part of a hostels social life (Murphy,2001). Pada dasarnya tempat tidur pada hostels terindikasi berada pada area privat. Namun kenyatannya private fungsi yang dimaksud dalam sebuah hostel adalah hanya private bed (tempat tidur) bukan private dalam artian ruang untuk tidur. Dalam satu ruangan terdapat 30 unit tempat tidur atau lebih (sharing room and bathroom). Salah satu model pengembangan hostels adalah Hostel Cube $(\mathrm{Hc})$ yang pertama kali dikembangkan di Oktogon Square pada tahun 2014. Beberapa prinsip dasar dari Hostels Cube adalah, "privacy tinggi, dilengkapi curtain, pengunjung dapat mengatur lampu tempat tidur sendiri, posisi tempat tidur berbeda-beda dalam setiap blok, dimensi unit berbeda disesuaikan dengan posisi badan. Prinsip struktur $\mathrm{Hc}$ adalah design dengan screw joint sehingga mudah dipasang dan dipindahkan sesuai dengan kebutuhan pengunjung.

Masing-masing orang memberikan pengertian berbeda terhadap hostels. Murphy (2001) menyebutkan bahwa hostel merupakan area komunal yang dilengkapi dengan fasilitas komunal, pengunjung sangat mudah bersosialisasi satu sama lain di dalam ruangan. Sedangkan Oliveira dan Brochado (2013) mengatakan bahwa tipikal hostel memiliki informal atmosfir jika dibandingkan dengan hotel, dan pengunjung hostels adalah wisatawan muda. Backpaking bukan merupakan tipe pariwisata baru. Jaringan wisatawan muda telah berasal dari beberapa dekade lalu. Namun, backpacker masa kini sifatnya lebih terbatas dan inflexible jika dibandingkan dengan kontemporer backpacking (Dallen J.Timothy, 2009).

Hasil penelitian Gergely dkk ini memberikan analisa berbeda tentang backpacker dari segi arsitektur. Penulis melihat bagaimana sosial ekonomi dan faktor urban menentukan design spasial sebuah backpacker hostel. Hostel di kawasan Budapest Hungaria dikategorikan ke dalam 3 (tiga) level. Yang pertama, investigasi hostels yang dibangun di area urban, dimana area urban ini memiliki karakteristik informality dan instability terhadap ekonomi dan isu operasional. Kedua, investigasi hostel berdasarkan skala arsitektur. Skala arsitektur disini dilihat berdasarkan data tingkat hunian hostels di Budapest, downtown historic building dan tingkat adaptasi bangunan terhadap lingkungan. Ketiga, investigasi terhadap interior ruangan dormitory. Interior hostel dianggap kurang memiliki privacy, oleh karena itu diperlukan sebuah solusi desain terhadap interior hostels, untuk meningkatkan privasi pengunjung.

Manusia dan alam lingkungan merupakan kesatuan yang tidak dapat dipisahkan, keduanya saling berinteraksi yang akan mempengaruhi pada tingkah laku manusia. Pola tingkah laku manusia berkembang menjadi kebudayaan dalam bentuk arsitektur (Trancik, 1986). Bertitik tolak dari hal tersebut dapat disimpulkan bahwa antara manusia dengan ruang terdapat hubungan timbal balik yang saling berinteraksi dan saling mempengaruhi. Bentuk lingkungan erat hubungannya dengan ruang arsitektur. 
Bentuk ruang arsitektur tersebut dapat memberikan imajinasi terhadap kemungkinan bentuk sebuah kawasan terbangun.

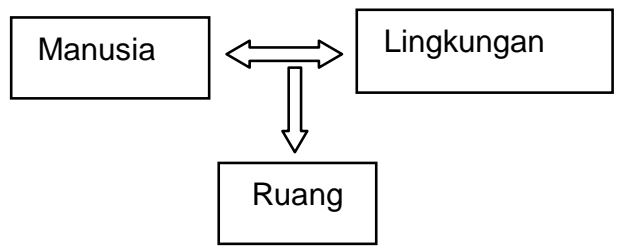

Gambar 1. Hubungan manusia lingkungan dan ruang

Sumber: analisa ulang, 2020

\section{Kerangka Konsep}

Konsep penelitian dari Gergely dkk ini merupakan komparasi dari pengalaman penulis dan hasil review literature yang kemudian ditindaklanjuti dengan metode observasi lapangan. Terdapat tiga variable yang dipakai untuk membuat evaluasi desain, diantaranya komponen interior, ruang kota, dan bangunan pembentuk ruang kota. Komponen informality, kepadatan (density), dan konsep penyesuaian diri. Hasil observasi yang telah dikomparasi dengan teori kemudian dipapaprkan dalam beberapa rekayasa desain. Rekayasa desain yang sudah terkumpul, dikembalikan kembali kepada pemilik akomodasi untuk dinilai kesesuaian, kenyamanan, tingkat kelayakan, dan kebutuhan pemilik akomodasi akan ruang-ruang yang akan disewakan. Hasil penilaian tersebut kembali di review dan di analisa untuk mendapatkan satu desain terbaik hasil pilihan owner dan wisatawan.

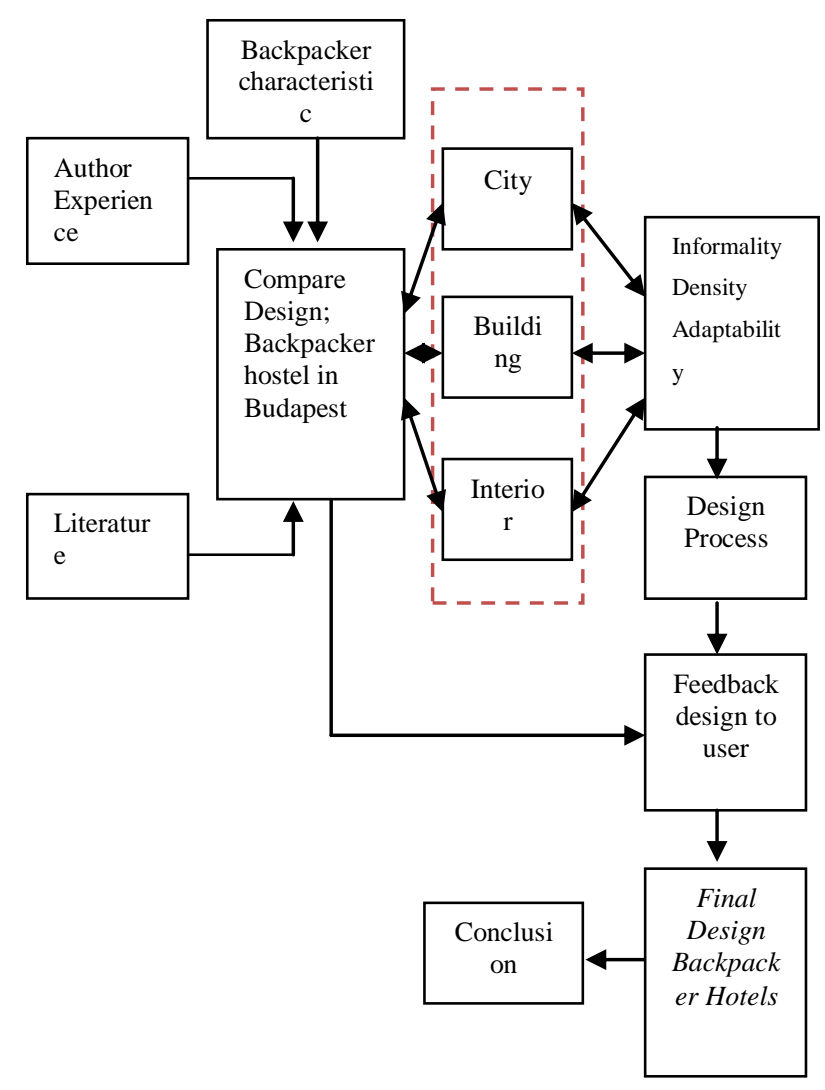

Diagram 2. Kerangka konsep pengembangan kawasan Budapest, Hungaria

Sumber: Analisa ulang konsep Gergely Horryn dkk (2017)

\section{Variabel Penelitian}

Penulis dalam penelitian ini menggunakan tiga variabel yaitu, city, building, dan interior. City yang dimaksud dalam penelitian ini adalah tempat dimana penelitian dilaksanakan, yaitu kawasan Budapest Hungaria. Isu yang diambil penulis di kawasan Budapest adalah perkembangan pembangunan hostels untuk Backpacker. Building yang dimaksud dalam paper ini adalah bangunan akomodasi wisata (hostels) yang khusus diperuntukkan bagi wisatawan backpacker. Dari keseluruhan bagian bangunan hostels, yang paling detail diteliti oleh penulis dalam penelitian ini adalah pengaturan interior terutama penempatan bed (tempat tidur) di dalam sebuah ruangan hostels. Bagaimana posisi tempat tidur yang paling efektif dan efisien, yang mampu memberikan privacy yang lebih baik untuk bangunan dengan type sharing room.

Populasi penelitian ini terdiri atas backpacker hostels di Kawasan Budapest yang dibangun pada periode tahun 2013- 2015. 
Namun dari semua populasi yang ada, yang dijadikan sample hanya enam hostel dan yang dianggap memenuhi kriteria adalah empat hostels.

Isu Spasial Hostels di Kawasan Budapest (Three interconnected levels; city, building, dan interior).

"What is the WIFI password, and where is the Szimpla?" kalimat tersebut merupakan kalimat pertama yang paling banyak diucapkan wisatawan yang mengunjungi hostels di Budapest (Origo, 2014). Szimpla adalah salah satu tempat yang paling populer di Budapest. Szimpla dibuka pada tahun 2004, dengan lokasi di jalan Kazinczy. Low cost airlines, dan harga akomodasi yang murah merupakan faktor yang paling signifikan yang mempengaruhi kunjungan wisatawan ke Budapest. Berdasarkan hasil survey POTM (2013), Budapest merupakan tempat wisata yang paling cocok diperuntukkan untuk wisatawan muda yang memiliki budget yang rendah. Penulis mulai mengumpulkan data tentang hostels di Budapest pada tahun 2015 yang memfokuskan lokasi di sisi timur Danube, central district, di dalam Grand Boulevard, yang memiliki jarak sangat dekat dengan public transport.

Penulis menemukan ada 108 Hostels yang ada di kawasan penelitian dengan jarak kira-kira 4 (empat) kilometers. Namun banyak hostels yang tidak teregistrasi dalam data pemerintah maupun di hostelsword.com. Sebagai perbandingan, data base yang sama 23 hostels di Vienna dan 83 di Prague. Dari 108 hostel yang teridentifikasi tersebut, 50 Hostels memiliki kapasitas kurang dari 30 tempat tidur, 36 hostels memiliki 30-80 tempat tidur dan 16 yang dioperasikan dengan 80 tempat tidur. Terdapat 4 (empat) hostels yang dibuka sebelum tahun 2005, 52 hostels yang dibuka antara tahun 20052010 dan 52 hostels sisanya dibuka setelah tahun 2010. Data ini menunjukkan bahwa data periode operasional yang sangat pendek sangat relevan dengan fenomena, dan faktor ini merupakan sebuah pertimbangan penting yang harus diingat pada saat melakukan proses desain.

Berdasarkan data yang diperoleh dari pihak manajemen hostels yang bersumber booking websites, tidak ada satupun bangunan yang bertujuan untuk menjadi ikon khusus. Data tersebut menunjukkan bahwa hostels yang ada di Budapest dibangun berdasarkan konsep dasar yang sama, dengan ukuran yang berbeda dan berlokasi di downtown apartemen. Target investasi wisatawan Budapest adalah wisatawan yang berasal dari Western-European. Dalam analisis yang sama pada February 2017, penulis menemukan bahwa hanya 82 hostels, 15 hostels yang dibuka setelah tahun 2015 . Ini menunjukkan bahwa hanya $62 \%$ dari hostels yang di investigasi sejak tahun 2015 yang masih beroperasi sampai tahun 2017. Setelah dilakukan invetigasi lebih jauh, ternyata banyak hostels yang ada di Budapest yang tidak terdaftar pada jaringan booking online seperti booking.com. Sebagian besar dari hostels tersebut menjadi anggota dari organisasi yang berskala kecil. Adapun klasifikasi hostels di Budapest dapat dilihat pada tabel berikut.

Tabel1. Klasifikasi Hostels di Budapest

\begin{tabular}{|c|c|c|c|}
\hline & Hostel Kecil & $\begin{array}{l}\text { Hostel } \\
\text { Sedang }\end{array}$ & Hostel Besar \\
\hline Lokasi & $\begin{array}{l}\text { Apartemen } \\
\text { kecil dengan } \\
\text { kapasitas 2- } \\
3 \text { kamar }\end{array}$ & $\begin{array}{l}\text { Apartemen } \\
\text { besar } \\
\text { dengan } \\
\text { kapasitas } \\
\text { 5-10 kamar }\end{array}$ & $\begin{array}{l}\text { Seluruh } \\
\text { bangunan atau } \\
\text { seluruh lantai } \\
\text { bangunan }\end{array}$ \\
\hline $\begin{array}{l}\text { Fungsi } \\
\text { sebelumn } \\
\text { ya }\end{array}$ & Residential & $\begin{array}{l}\text { Kantor, } \\
\text { atau fungsi } \\
\text { sejenis } \\
\text { lainnya }\end{array}$ & $\begin{array}{l}\text { Fungsi } \\
\text { sebelumnya } \\
\text { pada saat } \\
\text { pembangunan } \\
\text { hostels besar } \\
\text { tidak menjadi } \\
\text { pertimbangan } \\
\text { utama, karena } \\
\text { alternatif } \\
\text { perubahan } \\
\text { total sangat } \\
\text { memungkinka } \\
\mathrm{n} \text { pada saat } \\
\text { perancangan } \\
\text { hostels yang } \\
\text { besar. }\end{array}$ \\
\hline $\begin{array}{l}\text { Operasio } \\
\text { nal }\end{array}$ & $\begin{array}{l}\text { Satu orang } \\
\text { pengelola } \\
\text { mengerjakan } \\
\text { semua } \\
\text { tugas. } \\
\text { Pemilik } \\
\text { sekaligus } \\
\text { sebagai }\end{array}$ & $\begin{array}{l}\text { Staff dan } \\
\text { karyawan } \\
\text { terdiri atas } \\
\text { volunters }\end{array}$ & $\begin{array}{l}\text { Dalam hostels } \\
\text { besar, semua } \\
\text { manajemen } \\
\text { adalah orang- } \\
\text { orang ahli dan } \\
\text { professional di } \\
\text { bidangnya }\end{array}$ \\
\hline
\end{tabular}




\begin{tabular}{|c|c|c|c|}
\hline & $\begin{array}{l}\text { resepsionis } \\
\text { dan manajer. }\end{array}$ & & \\
\hline $\begin{array}{l}\text { Peran } \\
\text { arsitek }\end{array}$ & $\begin{array}{l}\text { Tidak } \\
\text { diperlukan } \\
\text { jasa arsitek } \\
\text { dalam } \\
\text { pembanguna } \\
\text { n atau } \\
\text { pengembang } \\
\text { an hostels } \\
\text { kecil }\end{array}$ & $\begin{array}{l}\text { Dalam } \\
\text { hostels } \\
\text { yang } \\
\text { berskala } \\
\text { menengah, } \\
\text { penggunaa } \\
\mathrm{n} \text { jasa } \\
\text { arsitek } \\
\text { tergantung } \\
\text { pada } \\
\text { keputusan } \\
\text { pemilik } \\
\text { akan } \\
\text { mempergu } \\
\text { nakan jasa } \\
\text { arsitek atau } \\
\text { tidak }\end{array}$ & $\begin{array}{l}\text { Peran arsitek } \\
\text { tidak bisa } \\
\text { dihindarkan } \\
\text { dalam } \\
\text { pembangunan } \\
\text { hostels besar. } \\
\text { Kompleksitas } \\
\text { desain dan } \\
\text { pengelolaan } \\
\text { ruang yang } \\
\text { banyak sangat } \\
\text { memerlukan } \\
\text { jasa arsitek } \\
\text { untuk } \\
\text { mengatur } \\
\text { efisiensi ruang. }\end{array}$ \\
\hline $\begin{array}{l}\text { Harapan } \\
\text { finansial }\end{array}$ & $\begin{array}{l}\text { Anggaran } \\
\text { yang rendah, } \\
\text { pendapatan } \\
\text { kecil }\end{array}$ & $\begin{array}{l}\text { Anggaran } \\
\text { rendah, } \\
\text { harapan } \\
\text { terhadap } \\
\text { pendapatan } \\
\text { cukup } \\
\text { besar }\end{array}$ & $\begin{array}{l}\text { Anggaran } \\
\text { tinggi } \\
\text { dibarengi } \\
\text { dengan } \\
\text { harapan } \\
\text { pendapatan } \\
\text { yang tinggi }\end{array}$ \\
\hline $\begin{array}{l}\text { Wajah } \\
\text { kota }\end{array}$ & Tidak ada & $\begin{array}{l}\text { Tidak ada } \\
\text { atau } \\
\text { sengaja } \\
\text { disembunyi } \\
\text { kan }\end{array}$ & $\begin{array}{l}\text { Bergantung } \\
\text { pada substansi } \\
\text { kota yang } \\
\text { dikembangkan }\end{array}$ \\
\hline
\end{tabular}

Sumber: Gergely Horryn dkk (2017) dibahasakan kembali, 2020

Neuwirth (2011) menyebutkan bahwa Budapest hostels are "businesses that exist solely through individual effort with no help from the government". Kebijakan ini sangat mempengaruhi perkembangan hostels di Budapest. Hostels-hostels yang ada bersumber dari private investor. Hostels merupakan budget akomodasi yang identik dengan low comfort (tingkat kenyamanan yang lebih rendah dari hotel). Data tersebut memberikan konsekuensi bahwa, hostels industri di Budapest berkembang secara dinamis. Jadi proses desain harus memperhatikan komponen tersebut. Desain proses fokus pada flexibilitas fisik, demountability, transformability, and movability sehingga tidak terjadi intervensi dalam pola spasial ruang.

Apabila kemudian dilihat berdasarkan tingkat hunian dan sejarah perkembangan bangunan, Hostels di Budapest mengalami beberapa perkembangan. Pada dekade tahun 90-an mereka menggunakan "capital style" yang dekat dengan urban block system. Bentuk ini termasuk street line, maksimum $85 \%$ area terbangun. Blok bangunan dibagi menjadi regular plot dimana masing-masing plot dipenuhi dengan parsial building dalam street line.

Fakta lain dari hostels yang ada di Budapest adalah, jangka waktu operasionalnya. Operasional hostels paling efektif selama tiga tahun. Hal ini dipengaruhi oleh interior design, dan pola hunian jangka pendek sehingga berdampak pada biaya pemeliharaan lebih tinggi daripada pemasukan. Dengan kapasitas 30 orang dalam sebuah ruangan, membuat peluang terjadinya kerusakan fasilitas semakin besar, karena ruangan dimanfaatkan secara bersama dalam waktu yang sama. Untuk itu diperlukan sebuah desain struktur hostels yang bersifat flexible (mampu mengakomodasi kunjungan jangka pendek, dengan harga yang terjangkau). Struktur dan pola ruangan bisa dioperasikan secara mandiri oleh wisatawan, dengan sirkulasi ruang yang tidak membingungkan. Tidur adalah aktivitas privacy manusia, sehingga desain tempat tidur harus mampu membentuk sebuah ruang yang membuat manusia merasa terlindungi selama dalam keadaan tidur. Oleh karena itu, hipotesis awal dalam penelitian ini adalah "sleeping unit different with living unit are needed to fulfill special requirements". Intervensi terhadap interior dapat mempengaruhi pola permukiman dan urban level.

\section{Eksperimental Design; Hostel Cube}

Penulis dalam paper ini mengembangkan eksperimen struktur hostel yang berwujud dormitory dengan tujuan untuk menyediakan akomodasi sambil mengenal karakteristik sejarah Budapest. Seperti yang telah dijelaskan pada sub bab sebelumnya, terdapat tiga variabel yang dipergunakan dalam penelitian ini, diantaranya adalah pembahasan hubungan antara reaksi antara ruang dan isu yang berkembang di dalamnya, sejauh mana bangunan bisa mewadahi nilai sejarah yang telah diwariskan secara turun temurun, dan terakhir adalah bagaimana akomodasi baru yang akan dirancang 
di Budapest, mampu mengakomodasi fenomena urban yang berkembang saat ini di Hungria.

Reacting to spatial interior issues. Dalam melihat hubungan ruang dengan isu spasial, komponen utama yang dipergunakan objke analisa oleh penulis adalah penempatan posisi tempat tidur di dalam sebuah ruangan hostel. Perletakan tempat tidur sangat menentukan jumlah tempat tidur yang bisa diwadahi oleh sebuah ruangan. Penempatan posisi tempat tidur yang salah, dapat menurunkan nilai ekonomis sebuah ruang, serta penurunan kualitas sirkulasi udara di dalam ruang. Oleh karena itu, rekayasa ulang terhadap penempatan posisi tempat tidur sangat diperlukan, dengan cara membuat beberapa alternative desain posisi dan jumlah perletakan tempat tidur. Selanjutnya adalah, Reacting to spatial issues of occupied historic building. Faktor nilai dan sejarah kawasan Budapest, menjadi pertimbangan utama dalam pengembangan seluruh aspek yang ada di kawasan ini.

\section{Dikutip}

dari

https://id.wikipedia.org/wiki/Budapest, sejarah Budapest dimulai oleh kota Aquincum yang awalnya merupakan permukiman Kelt dan kemudian menjadi ibu kota provinsi Romawi yang disebut Pannonia Inferior. Bangsa Hongaria tiba di wilayah Budapest pada abad ke-9. Permukiman pertama mereka dijarah oleh bangsa Mongol pada tahun 1241. Kota yang telah didirikan kembali lalu menjadi pusat budaya humanisme Renaisans pada abad ke-15. Setelah kekalahan besar Hongaria dalam Pertempuran Mohács dan periode kekuasaan Kesultanan Utsmaniyah selama hampir 150 tahun, kawasan ini memulai lembaran baru sebagai kawasan yang sejahtera, dan Budapest menjadi kota global setelah disatukannya kota Buda dan Óbuda di tepi barat Sungai Donau dengan kota Pest di tepi timur pada tanggal 17 November 1873. Setelah ditetapkannya kompromi Austria-Hongaria pada tahun 1867, Budapest menjadi salah satu ibu kota kekaisaran

Austria-Hongaria, sebuah kekuatan besar yang akhirnya bubar pada tahun 1918 akibat kekalahannya dalam Perang Dunia I. Kawasan kota ini juga pernah menjadi lokasi Revolusi Hongaria pada tahun1848, Pertempuran Budapest pada tahun 1945, dan Revolusi Hongaria 1956. Kini, Budapest berkembang menjadi kota terbaik kedua di eropa oleh Condé Nast Traveler, dengan pemandangan dan museum-museum nya yang sangat indah.

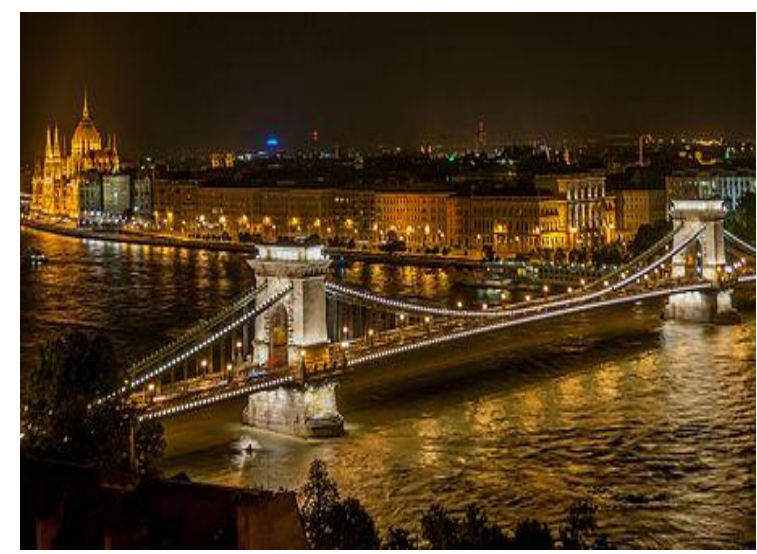

Gambar 1. Kawasan pariwisata Budapest, Hungaria

Sumber: https://id.wikipedia.org/wiki/Budapest

Dalam perkembangannya, Budapest mulai dikembangkan menjadi kota wisata dengan beragam jenis akomadasi yang dibangun di dalamnya. Akomodasi favorit di kawasan ini adalah hostels. Hostels yang ada di Budapest sebagian besar memiliki koridor di tengah ruang dengan lebar corridor mencapai 6 (enam) meter, dengan ketinggian lantai 3-4 meter. Koridor menjadi ruang heterogen, dan banyak ruang terbuang akibat lebar koridor yang terlalu besar. Berdasarkan kondisi ini, penulis kemudian memberikan solusi sebuah Hostels Cube yang mana dalam penelitiannya ini istilah hostels cube disingkat HC. Design ini kemudian dianggap mampu memberikan privacy yang lebih tinggi terhadap wisatawan, walaupun konsep ruang masih tetap sama yaitu sharing room. 


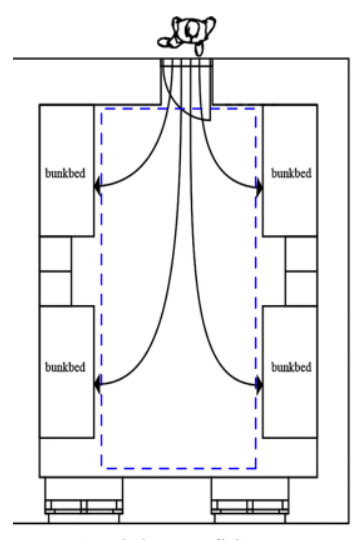

conventional arrangenentut of bedis

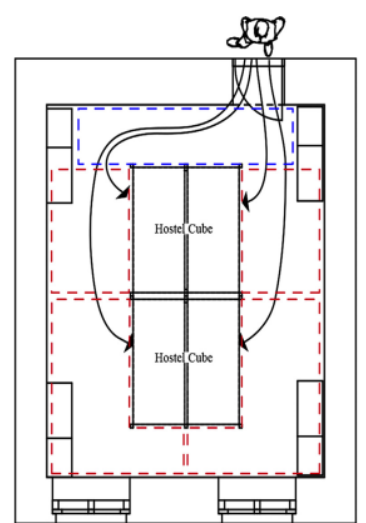

arrangemenen of beds with the Hostel Cule
Gambar 2. Alternative desain hostels di Budapest, Hungaria

Sumber: Gergely Horryn dkk (2017)

Reacting to spatial issues of the urban position of hostels. Hostels di Budapest tidak hanya menyediakan akomodasi untuk wisatawan yang bersifat berpindah-pindah, namun masyarakat Budapest juga memiliki kebiasaan berpindah-pindah, sehingga design spasial ruangan hostels harus mampu mengakomodasi kebiasaan hidup masyarakat Budapest. G. Deleuze dan F. Guattari dalam $A$ Thousand Plateaus (1988) mengungkapkan tentang istilah nomadologi yang merupakan ilmu yang mempelajari tentang bentuk pergerakan manusia. Adapun teori pergerakan yang paling terkenal adalah teori "on the move" dari Cresswell (2006). Creswell mengungkapkan bahwa dalam hal pergerakan manusia (mobilitas) ada tiga isu utama yang sangat penting diantaranya, pergerakan sebagai fakta yang terukur dan terobservasi secara empiris yang telah terbukti dalam teori perencanaan dan migrasi. Selanjutnya mobilitas ditampilkan sebagai sebuah model representative seperti film, fotografi, filsafat, hukum dan sebagainya. Ketiga adalah momen dari pergerakan itu sendiri yang merupakan pengejawantahan pengalaman individu pada saat melakukan perpindahan dari satu tempat menuju tempat yang lain. Perubahan lokasi tujuan pergerakan dibarengi dengan perubahan tema dari tahun ke tahun. Pergerakan manusia yang pada awalnya didasari oleh perlindungan diri dari musuh, kini telah berubah menjadi sebuah trend liburan untuk menenangkan pikiran atau menghabiskan waktu luang bersama keluarga. Identitas dan konsep pergerakan inilah yang sangat wajib diamati oleh seorang arsitek ketika mendesain ulang sebuah kawasan. Pembentukan identitas kawasan sangat bergantung pada orang yang datang untuk memanfaatkan kawasan tersebut, penduduk asli sebagai pelestari budaya dan penduduk yang pergi sebagai evaluator negative kota, karena lebih memilih meninggalkan tempat tersebut.

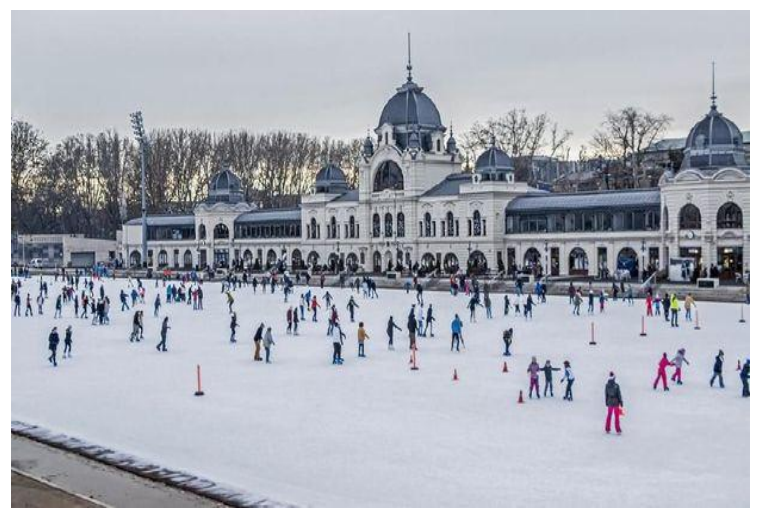

Gambar 3. Mobilitas wisatawan backpacker di City Park Ice Rink di Budapest

Sumber: https://travel.detik.com/internationaldestination/d-4817695/inikah-tempat-terbaikmenikmati-musim-dingin-di-eropa

\section{Kesimpulan}

Berdasarkan hasil tinjauan Gergely Horryn dkk (2017), ditemukan tiga variable yang mempengaruhi spasial design backpacker hostels yang ada di Budapest. Yang pertama adalah city (nilai sejarah kota Budapest) yang mengalami perkembangan pesat di bidang pariwisata sehingga permintaan akan akomodasi semakin meningkat. Kedua adalah interior. Pengaturan posisi furniture di dalam ruangan hostels sangat mempengaruhi nilai ekonomis, sirkulasi udara serta interaksi wisatawan dengan sesame wisatawan di dalam sebuah ruang. Yang ketiga adalah wujud tampilan bangunan. Mengingat nilai sejarah yang dimiliki kota Budapest, maka wujud tampilan bangunan semaksimal mungkin wajib dibuat sama dengan bangunan bersejarah yang ada di sekitarnya. Kondisi ini mengharuskan adanya pemikiran lebih mendalam untuk pengembangan kota ini kedepannya. Solusi design yang disimpulkan 
penulis adalah hostels cube $(\mathrm{Hc})$ dengan screw joint yang dianggap lebih efektif dan efisien. Bangunan dipandang memerlukan setting fisik. Dalam kasus backpacker hostels, direkomendasikan untuk meletakkan posisi tempat tidur di tengah ruangan. Posisi tersebut dianggap lebih memberikan privacy terhadap wisatawan. Dalam pengembangan Interior, yang paling dikritisi adalah corridor yang lebar di tengah ruangan yang mengubah area privat menjadi area publik, sehingga salah satu solusi yang direkomendasikan adalah tempat tidur dengan curtain (tirai), lampu privat, dan locker di sebelah tempat tidur.

Mengkaji lebih jauh tentang informality, density dan adaptability. Pelaku usaha akomodasi berusaha bersembunyi dari tekanan ekonomi dan pajak sehingga berusahan membuat sebuah akomodasi dengan konteks physical urban fabric. Sistem pemasaran dari mulut ke mulut membuat akomodasi hostels sangat diminati. Namun dalam pembangunannya, tidak serta merta mengubah total wujud bangunan yang telah ada, namun pertimbangan flexibilitas ruang dan ketersedian modal menjadi pertimbangan utama dalam melakukan perubahan. Informality disini bukan berarti illegal secara hukum, namun lebih menekankan pada konteks sembunyi secara desain, fungsi dan fisik bangunan.

Berinjak pada variabel density. Analisa terhadap density merupakan isu utama yang wajib dipertimbangkan sebelum mengembangkan sebuah ruang. Kepadatan penduduk sekitar dan perkiraan jumlah wisatawan yang datang per tahun sangat berpengaruh terhadap bentuk dan besaran ruang yang akan dibentuk. Dalam decade tearkhir, kunjungan wisatawan ke Budapest lebih tinggi jika dibandingkan dengan wilayah Prague atau Vienna, sehingga jumlah akomodasi yang disediakan juga lebih banyak. Terakhir adalah adaptability. Peningkatan jumlah akomodasi hostels di Budapest merupakan sebuah bentuk adaptasi terhadap peningkatan jumlah kunjungan wisatawan. Namun, nilai sejarah yang dimiliki oleh kota Budapest ini juga memerlukan tingkat penyesuaian pembangunan yang tinggi. Bagaimana membuat sebuah desain akomodasi urban modern tanpa menghilangkan nilai sejarah yang terkandung di dalamnya. Konsep ini sangat tidak mudah. Penyesuaian aktivitas dan perilaku penduduk asli yang ada di Budapest wajib menjadi masukan dalam menampilkan sebuah tampak dan interior bangunan. Berdasarkan hasil analisa Gergely Horryn dkk, Hostels Cube $(\mathrm{Hc})$ dianggap sebagai desain yang paling bisa mewadahi informality, density dan adaptability kawasan Budapest yang semakin lama semakin pudar.

\section{Daftar Pustaka}

Budiharsono, D.I.S. 2001. Teknik Analisis Pembangunan Wilayah Pesisir dan Lautan, Jakarta, PT. Pradnya Paramitha

Cohen, E. (1973) Nomads from Affluence: Notes on the Phenomenon of Drifter Tourism, International Journal of Comparative Sociology.

Cresswell, T. (2006) On The Move: Mobility in The Modern Western World, Routledge, London UK

Dallen J. Timothy, V.B.T. 2009. Tourism and the Lodging Sector, United State of America, Elsevier

Hory Gergely, Z. M., Peter Mullner, Melinda Benko. (2017). Exploration of Spatial Design Issues at Backpacker Hostels in Budapest's Historic Center: Informality, Density, Adaptability. Frontiers of Architectural Research, 6, 157-168.

Murphy, L. and Pearce, P. (1995) Young Budget Traveller: Backpackers in Australia, Annals of Tourism Research 22 (4) 819843.

Pitaya, M., Baiquni, Marsono, Nopirin. (2019). Paradigma Historis Backpacking Travel Sebagai Perjalanan Wisata. Jurnal Pariwisata Terapan, 3(01), 34-54. doi:https://doi.org/10.22146/jpt.48834

Trancik, R. 1986. Findings Lost Space: Theories of Urban Design, Canada, John Willey \& Son Inc. 